\title{
Morphologycal and Molecular Partial Histone-H3 Characterization of Bintan Sea Snail Gonggong (Strombus sp.) as a Species Validation
}

\author{
Lily Viruly ${ }^{1 *}$, Nuri Andarwulan², Maggy T. Suhartono², Mala Nurilmala ${ }^{3}$ \\ 'Department of Aquatic Product Technology, Raja Ali Haji Maritime University, Riau Islands, Indonesia \\ ${ }^{2}$ Department of Food Science and Technology, Bogor Agricultural University, West Java, Indonesia \\ ${ }^{3}$ Department of Aquatic Product Technology, Bogor Agricultural University, West Java, Indonesia
}

\section{ARTICLE INFO}

Article history:

Received July 24, 2018

Received in revised form January 15, 2019

Accepted March 18, 2019

\section{KEYWORDS:}

Sea snail gonggong,

morphology,

molecular identification,

Strombus turturella

\begin{abstract}
Sea snail gonggong is an icon of Tanjungpinang-Riau Islands Province. It is a favorite seafood item in Riau Islands Province, and is high economic value but not known widely yet. Until now, sea snail gonggong has been highly exploited but the research on this snail is very limited. The aim of this study was to morphology and molecular characterization of Bintan gonggong snail (Strombus sp.) as a species validation. Bintan gonggong snail included thick-shelled gonggong and thin-shelled gonggong. Morphology identification of species Bintan gonggong snail was based on morphometric variability. Molecular identification used partial Histone-H3, MEGA version 6.06, and bioinformatics analysis. The result showed that the morphological identification of thick-shelled and thin-shelled gonggong based on shell width, the lip thickness, and total weight significantly different, but other variables (i.e shell length, shell depth, aperture length, and gonggong weight) were not significantly different $(\mathbf{p}<0.05)$. Resulted of a molecular identification with phylogenetic analysis that the thin-shelled and thick-shelled Bintan gonggong snails were 1 species and a genetic distance of $1 \%$. They were not species Strombus canarium, Strombus vitatus, and Strombus epidromis. Bintan gonggong snails were Strombus turturella (Leavistrombus turturella). DNA sequences of Bintan gonggong have been registered in Gen-Bank with registration numbers MH348131 (thinshelled gonggong) and MH348132 (thick-shelled gonggong).
\end{abstract}

\section{Introduction}

Gonggong is one type of marine biota in Riau Islands Province with good market value and it is known as "siput gonggong" (Strombus sp.) (Cob et al. 2009). Gonggong is an endemic biota that lives on Bintan Island and its surroundings, such as Dompak, Lobam, Mantang Island, Senggarang, and Tanjung Uban. Gonggong became the icon of Tanjungpinang, Riau Islands Province (Viruly 2012). Empirically of gonggong is known as vitality, enhanching foods and healthy foods, because it is believed to contain high protein. Gonggong is boiled water and it is eaten with sauce or peanut sauce (Amini 1986; Viruly 2012).

Studying gonggong is least. Preliminary study of gonggong is focused on proximation composition by Amini (1986), and amino acid, heavy metal by Viruly

\footnotetext{
* Corresponding Author

E-mail Address: ummufaqih@gmail.com
}

(2012); Muzaharand Viruly(2013). Biological diversity can be measured in ways ranging from simple counts of species or measured morphological diversity (Amini and Pralampita 1987). Until now, species gonggong has not been identified morphologically, because morphological of characterization gonggong is very complex. Morphological gonggong influenced by environment (habitat). Habitat's gonggong was the coastal areas and was highly associated with seagrass (Enhallus sp.) (Amini 1986). Information regarding morphology of gonggong is very limited and currently there is no regulation concerning the fishery of this species, whereas they are included ancient animals (Cob et al. 2008). Natural mortality rate of gonggong is the highest; this rate indicated that has been overexploited. The exploitation rate of gonggong $(E=F / Z)$ were 0.68 for males and 0.63 for females, which were higher than the optimum level of exploitation ( $\mathrm{E}=0.50$ ) (Cob et al. 2009; Cob et al. 2009b). According to Latiolais et al. (2006) that 
molecular phylogenetic of sea snail Leavistrombus (Strombus sp.) can be used primer histones subunit 3 ( $\mathrm{H} 3 \mathrm{~A}$ and $\mathrm{H} 3 \mathrm{~B}$ ), because primer $\mathrm{COI}$ proved problematic to sequence across full length. Therefore, the aim of this study was to identify morphology and molecular partial histone-H3 characterization of Bintan sea snails gonggong (Strombus sp.) to validate species identification.

\section{Materials and Methods}

\subsection{Sample Collection}

Live sea snail gonggong were collected from Madong village in Bintan Island, Riau Islands Province. They were collected from 4 stations (Figure 1 ). They were transported to laboratory in Bogor at August 2017. Gonggong from Bintan Island included thick-shelled and thin-shelled sea snails gonggong as many as 200 tails to morphological and molecular characterization of gonggong. In the laboratory, they were cleaned and separated to shape their shell (Cob et al. 2008).

\subsection{Morphometric Variability}

Samples of gonggong divided into different to shape their shell were thick-shelled and thin-shelled gonggong each 30 tails. Morphometric variability included shell length, shell width, shell depth, aperture length, lip thickness, gonggong weight, shell weight, and total weight. Morphometric characteristics of this spesies gonggong can known morphometric variability (Figure 2). Differences in specific morphometric parameters between two group gonggong analyzed via one-way ANOVA at

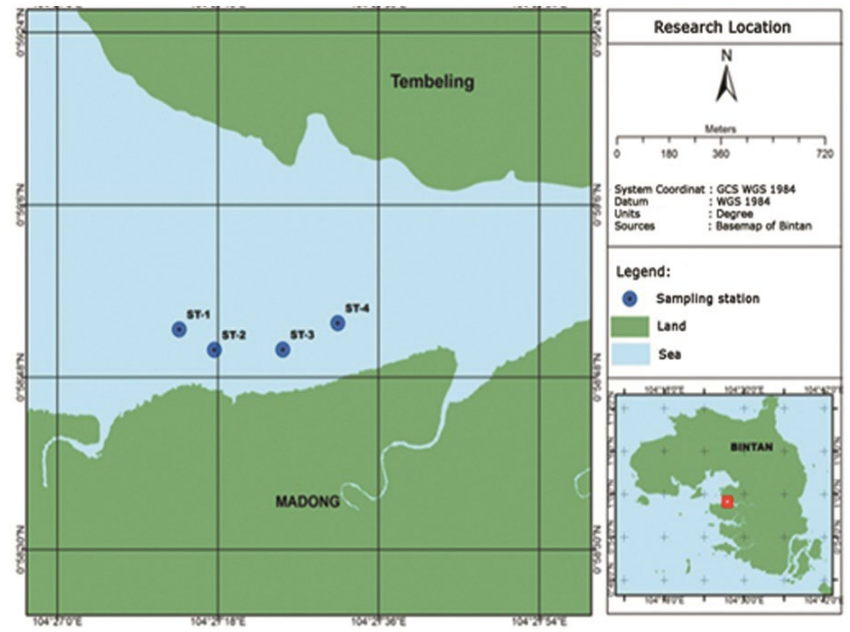

Figure 1. Map of sampling station $\mathrm{p}<0.05$ probability levels (Cob et al. 2008; Cob et al. 2009a, 2009b).

\subsection{Molecular Characterization of Bintan Gonggong Snail \\ 2.3.1. DNA Extraction and Isolation}

DNA extraction from gonggong samples (thickshelled and thin-shelled) was randomly carried out on 50 gonggong samples. $10-20 \mathrm{mg}$ of each sample were taken then placed into Eppendorf tubes. Afterward, $250 \mu \mathrm{l}$ of lysis cell solution and $1.5 \mu \mathrm{K}$ proteinase solution were added and homogenized for $3 \mathrm{sec}$. The sample was then vortexed for 1 second and incubated with a wobble at $55^{\circ} \mathrm{C}$ for 24 hours. The RNA was eliminated by adding 1.5 RNase ( $4 \mathrm{mg} /$ $\mathrm{ml}$ ) into Eppendorf and vortexed (in tubes) times, incubated at $37^{\circ} \mathrm{C}$ for 60 minutes, then incubated at room temperature. The protein sample was precipitated using a protein precipitation solution of $200 \mu \mathrm{l}$; vortexed for 30 seconds to homogenize and incubated in the freezer for 10-15 minutes. The sample was centrifuged at $12,000 \mathrm{rpm}$ for 10 minutes. $100 \%$ isopropanol (0.8 x DNA fluid volume) was added to the sample, and the tube was reversed 50 times, before being centrifuged at $12,000 \mathrm{rpm}$ for 10 minutes. The supernatant was removed, and $300 \mu \mathrm{l}$ of cold ethanol was added (70\%). The sample was centrifuged again at 12,000 rpm for another 10 minutes, and ethanol was discarded and dried for 30 minutes. After that, the sample was added $50 \mu \mathrm{l}$ Nuclease-Free Water (NFW) and heated to $50^{\circ} \mathrm{C}$ for 2 minutes. The solution was diluted 10 times (Latiolais et al. 2006).
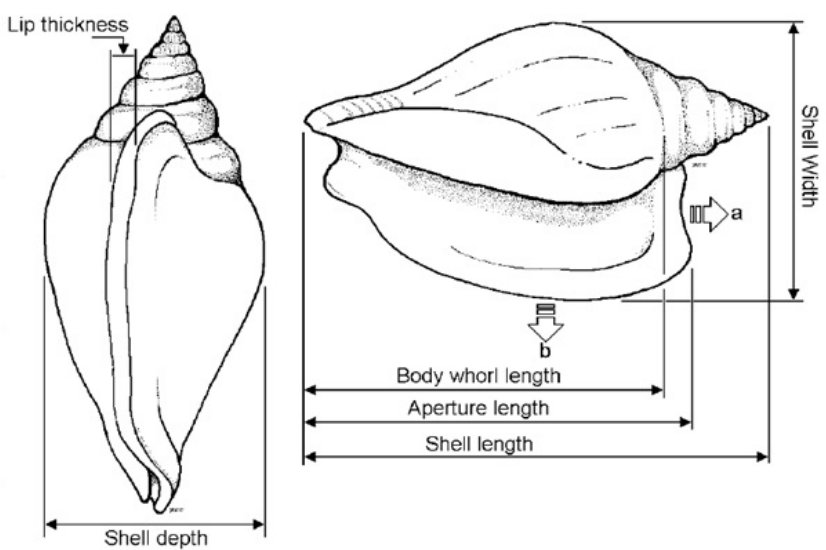

Figure 2. Morphometric variability of sea snail gonggong (Cob et al. 2008) 


\subsubsection{Amplification and Sequensing}

This study used $2 \mu \mathrm{l}$ DNA from each sample extraction. The intensification of sample was carried out using Polymerase Chain Reaction (PCR). All reactions were performed at a volume of $25 \mu$ l, consisting of $10 \mu l$ mixture (Mytaq, dNTP, DNA polymerase, and buffer), Histone $\mathrm{H} 3$ Primer(F) and Histone 141 H3 Primer $2 \mu \mathrm{l}$, NFW(ddH2O), respectively with a volume of $9 \mu$. The PCR was carried out under the following conditions: initial temperature of $94^{\circ} \mathrm{C}$ for 5 minutes, pre-denaturation at $94^{\circ} \mathrm{C}$ for 5 minutes, DNA denaturation at $94^{\circ} \mathrm{C}$ for 25 seconds, annealing at $57^{\circ} \mathrm{C}$ for 25 seconds, and extension at $72^{\circ} \mathrm{C}$ for 25 seconds, the final elongation temperature was $72^{\circ} \mathrm{C}$ for 5 minutes, and the total reaction was 40 cycles. The target amplification is at $350 \mathrm{bp}$ from the $\mathrm{H} 3$ histone protein. The sequencing using histone primer $\mathrm{H} 3 \mathrm{~A}$ is ATGGCTCGTACCAAGCAGACVGC-3', while the sequence of the H3B protein is 5'ATATCCTTRGGCATRATRGTGAC-3' (Colgan et al. 1998). The PCR reaction was visualized using $2 \%$ agarose gel and electrophoresis lasting for 30 minutes at $200 \mathrm{~V}$. This reaction produces a single band of the expected size ( $350 \mathrm{bp}$ ). All products are sequenced in both directions using fluorescently labeled dye-terminators (ABI, Foster City, CA) (Latiolais et al. 2006).

\subsubsection{Phylogenetic and Bioinformation Analysis}

All the nucleotide sequences are compared with other sequences from GenBank using the Basic Local Alignment Tool nucleotide (BLASTn) at NCBI (http:// www.ncbi.nlm.nih.gov/blast). The BLASTn program is used to analyze the nucleotide similar to Strombus sp. All sequences are available at Gen Bank-H3 for Strombus sp., Littorina sp., Biomphalaria sp., and Haliotis sp. Pairwise and multiple sequence alignment were analyzed using the ClustalW program. Phylogenetic tree was performed using the Neighbor-Joining from Mega version 6.06 (Latiolais et al. 2006).

\section{Results}

\subsection{Morphology Identification of Bintan Gonggong Snail}

Various morphometric parameters of spesies Bintan gonggong snail, Riau Islands Province were measured and analyzed. The parameters included shell length, shell width, shell depth, aperture length, lip thickness, gonggong weight, shell weight, and total weight (Table 1). Comparisons between thickshelled and thin-shelled sea snails gonggong were based on morphology indicated that thick-shelled and thin-shelled sea snails gonggong had shell width, lip thickness, and total weight significantly different $(\mathrm{p}<0.05)$, which shell length, shell depth, aperture length, and gonggong weight were not significantly different (Table 1 and Figure 3 ).

Comparison of body, digestive, adult operculum, and male reproductive organs (penis) of the species were presented in Figure 3. The difference of morphology also occurred in body, digestive, adult operculum, and male reproductive organs (penis) (Figure 4), although they were very similar.

Morphologycal identification based of shell sharp were presented in Figure 5. Figure 5 showed that thin shell gonggong (gonggong tipis) and thick shell gonggong (gonggong tebal) were Laevistrombus turturella, but they were not Strombus canarium.

\subsection{Molecular Identification of Bintan Gonggong}

The identification of gonggong species based on morphology is complicated, leading to the need for gonggong molecular characterization. Thus, the molecular identification of gonggong used $\mathrm{H} 3$ Histone primers. The result of gonggong DNA extract amplification using PCR with Histone primer (Figure 6).

Table 1. Morphological comparisons between thick-shelled and thin-shelled of gonggong

\begin{tabular}{lll}
\hline Parameters & $\begin{array}{l}\text { Thick-shelled } \\
\text { gonggong }\end{array}$ & $\begin{array}{l}\text { Thick-shelled } \\
\text { gonggong }\end{array}$ \\
\hline Shell length $(\mathrm{cm})$ & $6.58 \pm 0.15^{\mathrm{a}}$ & $6.69 \pm 0.42^{\mathrm{a}}$ \\
Shell width $(\mathrm{cm})$ & $4.05 \pm 0.09^{\mathrm{b}}$ & $3.86 \pm 0.32^{\mathrm{c}}$ \\
Shell depth $(\mathrm{cm})$ & $2.95 \pm 0.10^{\mathrm{a}}$ & $2.99 \pm 0.25^{\mathrm{a}}$ \\
Aperture length $(\mathrm{cm})$ & $5.030 \pm 0.11^{\mathrm{a}}$ & $5.07 \pm 0.34^{\mathrm{a}}$ \\
Lip thickness $(\mathrm{cm})$ & $0.21 \pm 0.01^{\mathrm{b}}$ & $0.05 \pm 0.02^{\mathrm{c}}$ \\
Gonggong weight $(\mathrm{g})$ & $9.84 \pm 0.52^{\mathrm{a}}$ & $8.87 \pm 2.57^{\mathrm{a}}$ \\
Total weight $(\mathrm{g})$ & $28.34 \pm 2.02^{\mathrm{b}}$ & $24.69 \pm 4.60^{\mathrm{c}}$ \\
\hline
\end{tabular}

Value with different superscript in the same column is significantly different $(\mathrm{p}<0.05)$

*Average of ten data (duplicate in triple measurements)

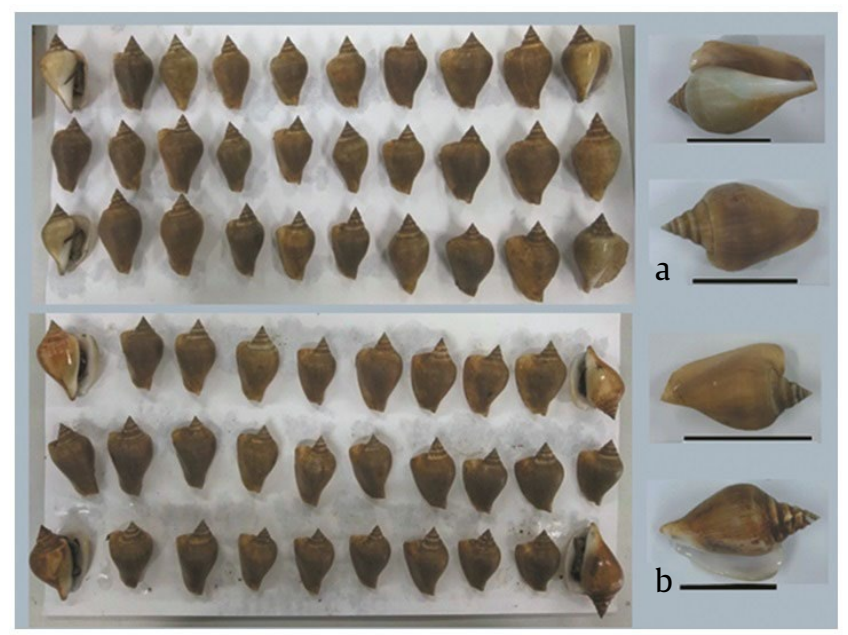

Figure 3. Sea snail gonggong from Bintan Island. (a) Thinshelled gonggong, (b) thick-shelled gonggong. Scale bars: $A, B=5 \mathrm{~cm}$ 

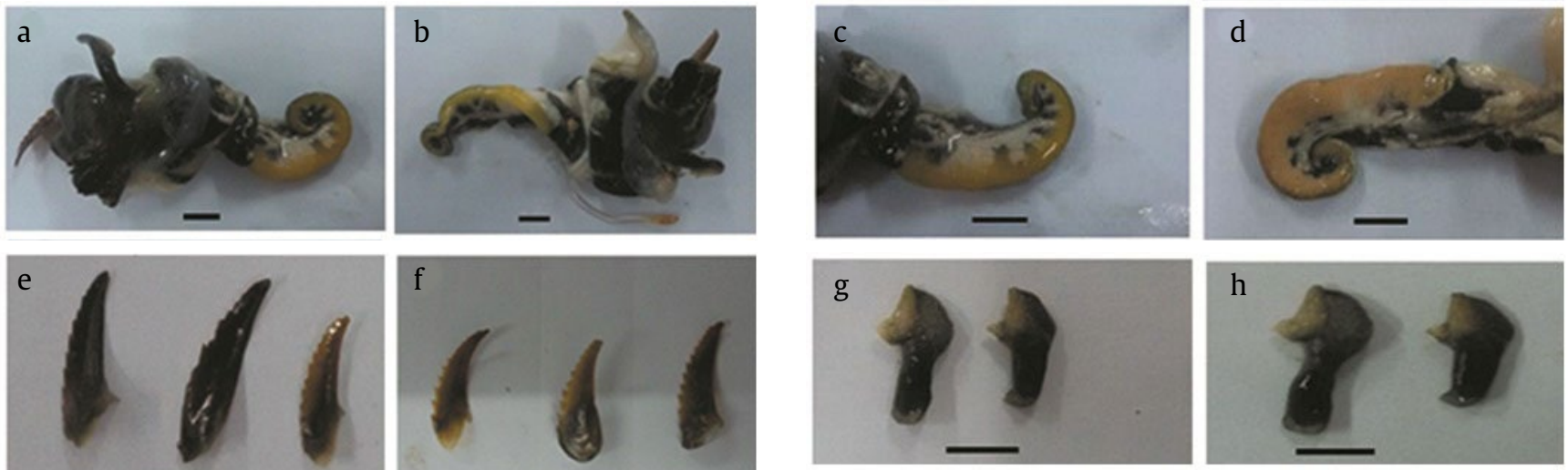

Figure 4. Physically comparison of between sea snails gonggong, thick-shelled gonggong (a, c, e, g); thin-shelled gonggong $(\mathrm{b}, \mathrm{d}, \mathrm{f}, \mathrm{h})$; body $(\mathrm{a}, \mathrm{b})$; digestive $(\mathrm{c}, \mathrm{d})$; adult operculum $(\mathrm{e}, \mathrm{f})$; penis $(\mathrm{g}, \mathrm{h})$. Scale bar: $1 \mathrm{~cm}$

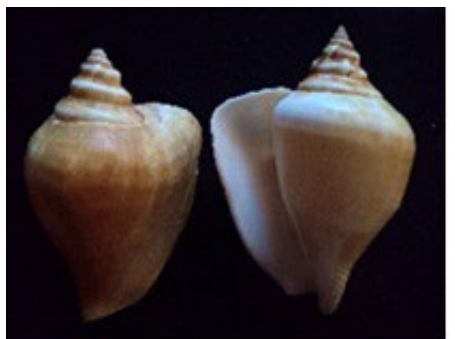

a. Thin shelled gonggong

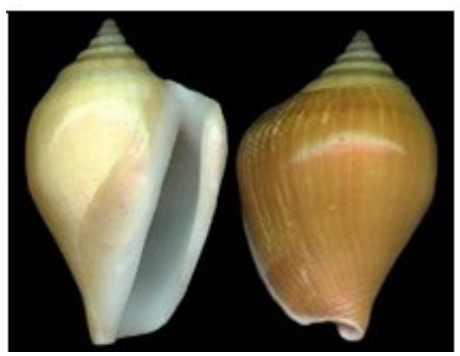

d. Strombus canarium

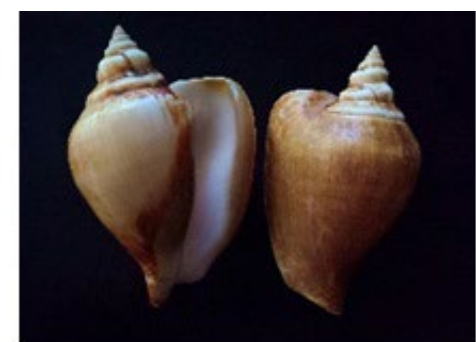

b. Thick shelled gonggong

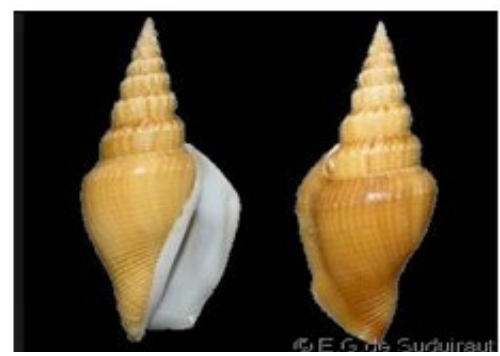

e. Strombus vitatus

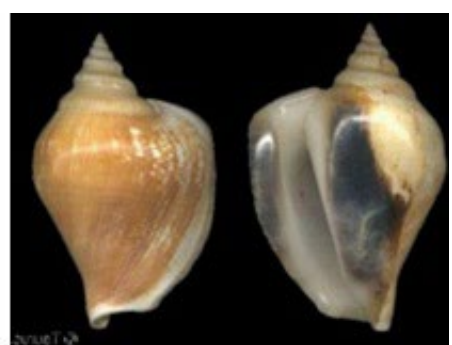

c. Laevistombus turturella

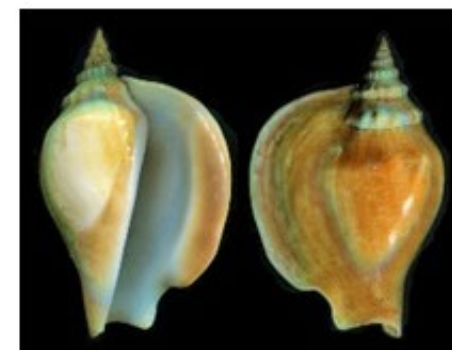

f. Strombus epidromis

Figure 5. Comparison of morphologycal identification based of shell sharp; Bintan gonggong snail: thin shelled gonggong (5a), thick shelled gonggong (5b); Mollusca Base 2018 (5c, 5d, 5e, 5f)

Nucleotide base sequence after alignment used BLASTn program (Table 2 and Figure 7). The construction of the phylogenetic tree (Figure 8).

\section{Discussion}

Differences in morphology of thick-shelled and thin-shelled sea snails gonggong were influenced by environment such as temperature, $\mathrm{pH}$, salinity, water depth, natural nursery, food, and level of pollution (Cob et al. 2010). Morphological of sea snails gonggong were strongly influenced by environment and food that largely the protein's gonggong so it was contributed to their phenotype. Furthermore, they are intertidal benthic organisms that protect them against pathogens with peptides protein in tissue of meat, so they have been antimicrobial compound. Those facts caused differences in their morphology (Cob et al. 2009a; Duval et al. 2009; Nam et al. 2015). So, the metamorphosis responses their larvae were influenced by the sediment and detrital substrata taken from their natural habitat (Cob et al. 2010).

ANOVA resulted that the species are different in shell width, lip thickness, and total weight; however, the two of sea snails species were still difficult to differentiate, because there were played that the difference other morphometric variables (shell length, shell depth, aperture length, and weight), more important also occurred in species identification based on morphology. Shell length is determinants on morphological identification. Shell length gonggong from researchers were variously, for example: 3.1-9.7 cm (Abbott 1960), $6.5 \mathrm{~cm}$ (Poutiers 1998), and 3.6-7.2 cm (Amini 1986). The sea snail gonggong of Bintan Island in this study is similar shell length studied by Amini (1986). 


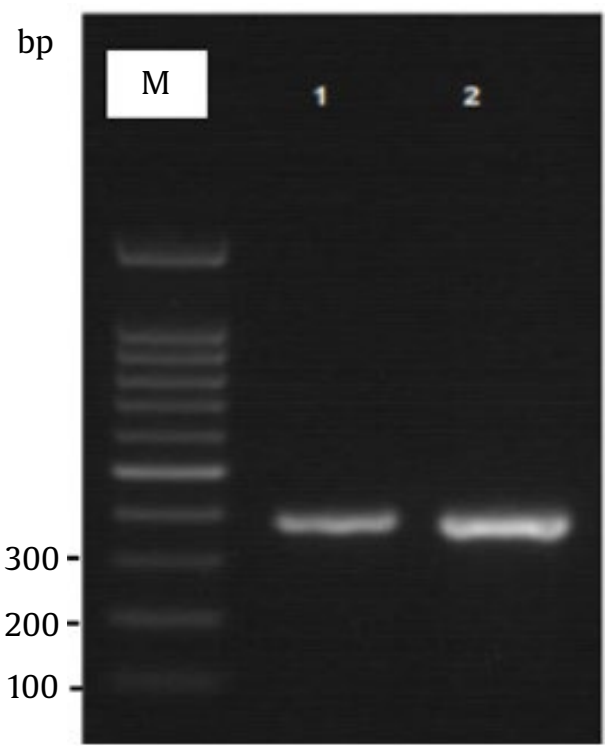

Figure 6. Visualisation of amplification genomic gonggong extraction. (1) Genomic thin-shelled gonggong extraction, (2) Genomic thick-shelled gonggong extraction. (M) Protein molecular weight marker
Thin-shelled gonggong is known as male gonggong (Cob et al. 2009a). According to Cob et al. (2008) that sea snails gonggong (Strombus canarium) are molluscs (gastropods) included male and female sex which can be distinguished by their shell size. The female gonggong has longer shell (male of $54.67 \pm 3.76 \mathrm{~mm}$; female $55.56 \pm 3.72 \mathrm{~mm}$ ), widher (male of $34.61 \pm 2.27$ $\mathrm{mm}$; female $35.38 \pm 1.99 \mathrm{~mm}$ ) but lip thickness (male of $3.32 \pm 1.93 \mathrm{~mm}$; female $2.83 \pm 0.87 \mathrm{~mm}$ ) than the male gonggong, but this research of Figure 3 showed that the male gonggong had penis and the female had not penis. Physically comparison of between thick-shelled

Table 2. BLASTn of thin-shelled and thick-shelled gonggong

\begin{tabular}{lcc}
\hline Species & Homology (\%) & No accession \\
\hline $\begin{array}{l}\text { Strombus epidromis gene } \\
\text { partial histone H3 }\end{array}$ & 99 & DQ525268.1 \\
$\begin{array}{l}\text { Strombus vittatus gene } \\
\text { partial histone H3 }\end{array}$ & 98 & DQ525269.1 \\
$\begin{array}{l}\text { Strombus canarium gene } \\
\text { partial histone H3 }\end{array}$ & 98 & DQ525245.1 \\
$\begin{array}{l}\text { Strombus wilsoni gene } \\
\text { partial histone H3 }\end{array}$ & 97 & DQ525249.1 \\
\hline
\end{tabular}

10

20

30

40

50

Gonggong_tipis Gonggong_tebal Strombus_vittatus Strombus_epidromis Strombus_canarium
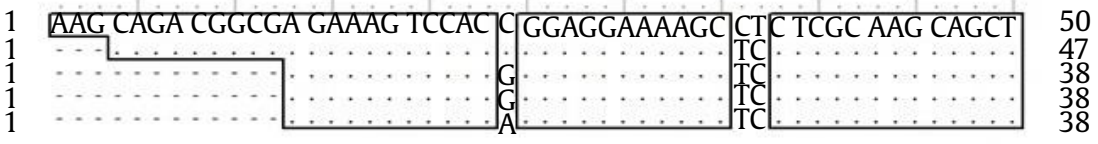

60

70

80

90

100
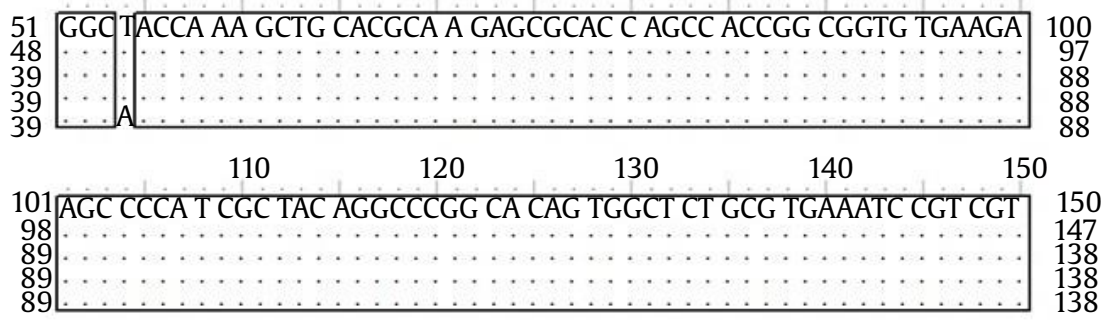

160

170

180

190

200
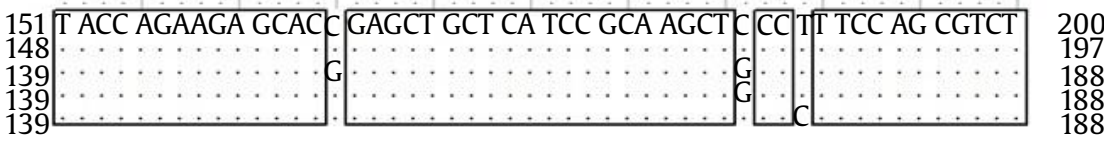

210

220

230

240

250

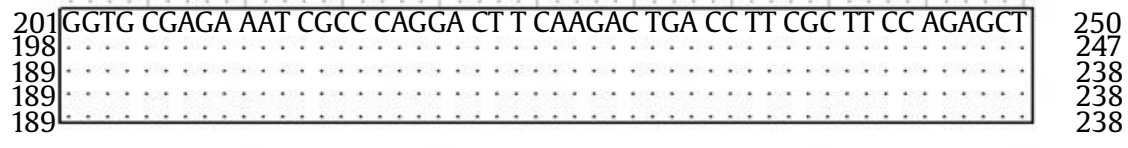

$\begin{array}{llll}260 & 270 & 280 & 290\end{array}$

Gonggong_tipis Gonggong_tebal

Strombus_vittatus

Strombus_epidromis Strombus_canarium
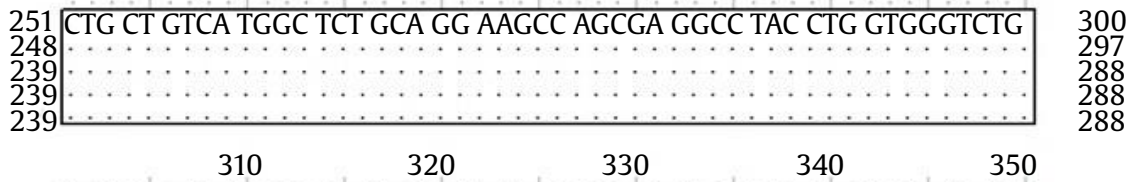

288

Gonggong_tipis

Gonggong_tebal

Strombus_vittatus

Strombus_epidromis

301 T TCACCA CACC AAC CTCT CCC CCA TCC AC CCC AACC CTC TCACC AT CA

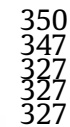

Figure 7. Nucleotide and amino acid sequences of gonggong. (1) Nucleotide and amino acid sequences of thick-shelled gonggong (gonggong tebal). (2) Nucleotide and amino acid sequences of thin-shelled gonggong (gonggong tipis) 


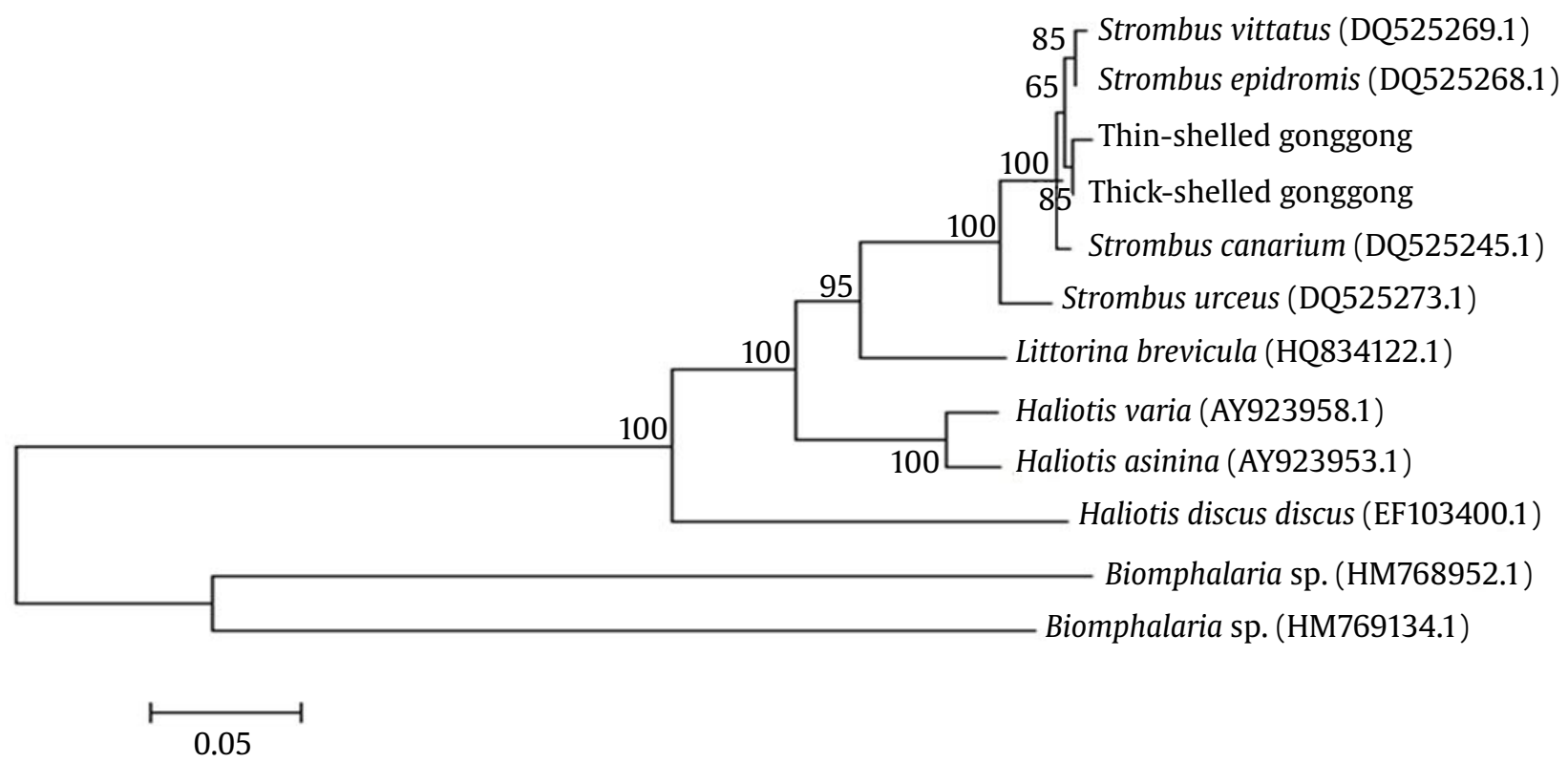

Figure 8. Phylogenetic tree of gonggong with other species from gastropoda

gonggong and thin-shelled gonggong were similar although shell phenotypes were different. In this fact, species gonggong has not been identified morphology directly, because characterization of morphological gonggong is very complex. Characteristics of gonggong with high morphological variations made they are difficult to identification. Thus, it has not been able to ensure thick-shelled and thin-shelled gonggong are one species. The identification of gonggong species based on morphologycal is complicated, so they will research for gonggong molecular characterization.

Figures 6 and 7 revealed that both thick-shelled and thin-shelled gonggong have similar nucleotide bases except for sites 36 and 37. Based on the BLASTn analysis, gonggong is closely related to Strombus epidromis (99\%) (Table 2). The analysis using MEGA 6.06 program revealed that thin-shelled gonggong was expected as genus Strombus of Indonesia origin. It has specific nucleotide base of 5 sites from nucleotide bases (having singleton on sites 38 and 39), on this site mutation of transition substitution (pyrimidine base "T-C" become a pyrimidine base " $\mathrm{C}-\mathrm{T}$ "). The opposite, thick-shelled gonggong was no mutation but also has 5 singleton sites. This condition indicated that Bintan gonggong snails were different from Strombus epidromis, Strombus canarium, and Strombus vitatus. Based on the analysis of the phylogenetic trees (Figure 8), both thick-shelled and thin-shelled gonggong were Strombus turturella (Leavistrombus turturella) species and were in one species as having a genetic distance of $1 \%$. If a genetic distance of $1 \%$ or less than $3 \%$ so in one species (Hebert et al. 2003). In the phylogenetic tree can also be predicted that Bintan gonggong snail was ancestors of Strombus epidromis and Strombus vitatus. DNA sequences of Bintan gonggong have been registered in Gen-Bank with registration numbers MH348131 (thin-shelled gonggong) and MH348132 (thick-shelled gonggong).

\section{Conclusion}

Morphology identification of spesies Bintan gonggong snails indicated that thick-shelled and thin-shelled gonggong had shell width, lip thickness, and total weight significantly different $(\mathrm{p}<0.05)$. The thin-shelled and thick shelled gonggong were in one species with a genetic distance of $1 \%$ which correspond to Strombus turturella (Leavistrombus turturella) species. Gonggong Bintan was predicted to be the ancestor of both Strombus epidromis and Strombus vitatus.

\section{Acknowledgements}

The authors are grateful to the Ministry of Research, Technology and Higher Education of The Republic of Indonesia, Director of the Southeast Asian Food and Agricultural Science and Technology (SEAFAST) Center-Bogor Agricultural University, Bogor-Indonesia and Maritime Raja Ali Haji University, TanjungpinangKEPRI-Indonesia.

\section{References}

Abbott RT. 1960. The genus Strombus in the Indo Pacific. Journal Indo-Pac Moll 1:33-146.

Amini S. 1986. Preliminary study of gonggong (Strombus canarium) in coastal waters of Bintan Island-Riau. Jurnal of Marine Fisheries Research 36:23-29. 
Amini S and Pralampita WA. 1987. Growth estimates and some biological parameters of gonggong (Strombus canarium) in coastal of Bintan Riau. Journal of Marine Fisheries Research 41:29-35.

Cob ZC et al. 2008. Sexsual polymorphism in a population of Strombus canarium Linnaeus 1758 (Mollusca: Gastropoda) at Merambong Shoal, Malaysia. Journal Zoological Studies 47:318-325.

Cob ZC et al. 2009. Age, growth, mortality, and population structure of Strombus canarium: Variation in male and female sub population. Journal of Applied Sciences 9:3287-3297.

Cob ZC et al. 2009a. Spesies description and distribution of Strombus (Mollusca: Strombidae) in Johor Straits and its surrounding areas. Journal Sains Malaysiana 38:39-46.

Cob ZC et al. 2009b. Development and growth of larvae of the dog conch, Strombus canarium (Mollusca: Gastropoda), in the laboratory. Journal Zoological Studies 48:1-11.

Cob ZC et al. 2010. Metamorphosis induction of the dog conch Strombus canarium (Gastropoda: Strombidae) using cues associated with conch nursery habitat. Journal of Applied Sciences 10:628-635.

Colgan DJ et al. 1998. Molecular phylogenetics of the Anthropoda: relationships based on histone $\mathrm{H}$ and U2snRNA DNA sequences. Australian Journal Zoological 46:419-437.
Duval E et al. 2009. KKKKPLFGLFFGLF: a cationic peptide designed to exert antibacterial activity. Journal Peptides 30:1608-1612.

Hebert PDN et al. 2003. Biological identifications through DNA barcodes. In: Proceedings of The Royal Society $B$. London: Royal Society Publishing. pp. 313-321.

Latiolais JM et al. 2006. A molecular phylogenetic analysis of strombid gastropod morphological diversity. Journal Molecular Phylogenetics and Evolution 41:436-444.

Mollusca Base. 2018. Laevistrombus turturella (Röding 1798). Available at: http://www.marinespecies.org/ aphia.php? $\mathrm{p}=$ taxdetails\&id=565670 [Data accessed: 13 January 2018]

Muzahar and Viruly L. 2013. Chemical characterization, sensory and spawning rate of gonggong (Strombus sp.) as icon Kepulauan Riau Province. Journal of Maritime Dynamics PPSPL UMRAH 2:20-29.

Nam BH et al. 2015. Functional analysis of pacific oyster (Crassostrea gigas) $\beta$-thymosin: Focus on antimicrobial activity. Journal Fish and Shellfish Immunology 45:167-174.

Poutiers JM. 1998. Gastropods. In The Living Marine Resources of The Western Central Pacific. Rome: FAO.

Viruly L. 2012. Utilization of broth bintan sea snail gonggong (Strombus canarium) Riau Islands as Natural Seasoning. Journal of Maritime Dynamics PPSPL UMRAH 1:36-59. 